\title{
PHYSICAL THERAPY AND MATERNITY SUPPORT GARMENT: INFLUENCE ON CORE STABILITY AND LOW BACK PAIN DURING PREGNANCY AND AFTER DELIVERY
}

\author{
Pavelas Zachovajevas ${ }^{1}$, Brigita Zachovajevien $\dot{e}^{2}$, \\ Jūratė Banionyte $\dot{\mathbf{e}}^{3}$, Arvydas Siaurodinas ${ }^{4}$ \\ Lithuanian Academy of Physical Education ${ }^{1}$, Kaunas, Lithuania \\ Lithuanian University of Health Sciences, Institute of Sport ${ }^{2}$, Kaunas, Lithuania \\ Kaunas Silainiai Outpatient Clinic ${ }^{3}$, Kaunas, Lithuania \\ Aleksandras Stulginskis University ${ }^{4}$ Kaunas, Lithuania
}

\begin{abstract}
Research background and hypothesis. Transversus abdominis muscle experiences extraordinary overstretching during gestation period and thus the ability of this muscle to stabilize spine decreases. These changes can cause chronic low back pain during pregnancy and after delivery. In order to solve this problem it is essential to apply proper and effective treatment methods. Hypothesis: physical therapy exercises are more effective than maternity support garment in low back pain treatment and core stability during pregnancy and after delivery.

Research aim was to evaluate the influence of physical therapy and maternity support garment on spinal stability and low back pain during pregnancy and after delivery.

Research methods. Study sample comprised 40 pregnant women. The assessments were made twice: at 28-35 weeks of gestation and 8-9 weeks after delivery. The low back pain was evaluated using SAS, core stability and transversus abdominis muscle activation were objectively tested using special device stabilizer and the presence of diastasis recti was tested as well.

Research results. Physiotherapy is $42.4 \%$ more effective than maternity support garment in low back pain control during pregnancy and after delivery $(\mathrm{p}<0.05)$. The best results of transversus abdominis muscle activation were observed in physiotherapy group with maternity support garment whereas participants without physiotherapy could not properly activate this muscle. The diastasis recti after delivery occurred only in control group, and in the group with maternity support garment it occurred $36.7 \%$ less frequently than in the group where women did not use this garment.

Discussion and conclusions. 1. Perceived low back pain after delivery was less expressed in women wearing maternity support garment both among women attending and not attending physiotherapy exercises. Nevertheless, physical therapy was more effective in reducing low back pain than maternity support garment during pregnancy and after delivery. 2. Core stability after delivery improved among women attending physical therapy exercises, but in case of maternity support garment it improved better. In contrast, in case of not attending physiotherapy the spinal stability after delivery improved only for women wearing maternity support garment. 3. Core stability during pregnancy and after delivery was better among women attending physical therapy but not wearing maternity support garment compared to women not attending physical therapy but wearing maternity support garment. 4. Physical therapy and maternity support garment improves core stability during pregnancy and has a positive effect on activity of rectus abdominis muscles following delivery.
\end{abstract}

Keywords: obstetrics, transversus abdominis muscle, exercises.

\section{INTRODUCTION} are determined by both mechanical and hormonal factors. During the growth and

development of uterus where the fetus is developing, the abdominal wall is gradually stretching and by the end of pregnancy the abdominal muscles are 
stretched reaching the limits of their elasticity. The muscles do not adapt timely to change of conditions of pregnancy and due to insufficient physical activity the muscle force and stamina decrease and coordination declines too. This leads to deteriorated function of muscles, joints and core stability (Zachovajevienè, 2006).

In scientific literature researchers often emphasize transversus abdominis muscle (TrA) that controls intraabdominal pressure through tension of thoracolumbar fascia. Together with multifidi muscles, thoracic diaphragm and pelvic floor muscles $\operatorname{TrA}$ secures core and pelvic stability as functional entity (Lee et al., 2008). After pregnancy, the trunk retains unstable as long as the function of supporting units does not reach the prior levels.

Different researchers claim that across various populations $24-90 \%$ of pregnant women suffer from low back pain (Sneag, Bendo, 2007; Kalus et al., 2008), which means that this is quite a frequent condition. Therefore many people including medical staff suppose that this is normal and will pass away in certain time (Žuromskis, 2008). However, the majority of women suffer such levels of pain that not only impair their working efficiency, but the quality of life during and after pregnancy as well (Gustafsson, Nilsson-Wikmar, 2008). In Lithuania, much attention is paid to health of pregnant women, however, it is not sufficient, especially regarding women who suffer pains and have reduced mobility during the pregnancy. Thus, it is not only important to define the cause of pain, but also to provide adequate help and care by effective means in reducing low back pain.

There are many studies conducted in Lithuania and other countries that prove positive effect of physiotherapy exercises on pregnant women, especially aimed to reduce low back pain (Garshasbi, Zadeh, 2005; Shia et al., 2005; Mørkved et al., 2007; Zachovajevienė et al., 2010; Gustafsson, NilssonWikmar, 2008). Similarly, there are several studies outside Lithuania that evaluated the effectiveness of maternity support garment in reducing of back and pelvic pain during the pregnancy (Catherine, 2003; Kalus et al., 2008). However, the majority of research assessed the effectiveness of physical therapy exercises or maternity support garment, but not both. Therefore it is very important to evaluate what is the synergistic effect of those two interventions applied for reduction of low back pain and core stability. Moreover, the research is mostly done only during the pregnancy and thus it is not clear what the outcomes following the delivery are.

The aim of the study was to evaluate the influence of physical therapy and maternity support garment on core stability and low back pain during pregnancy and after delivery. Hypothesis: physical therapy is more effective than maternity support garment in low back pain treatment during pregnancy.

\section{RESEARCH METHODS}

Study conduct and subjects. The study was conducted from July 2010 to April 2011. It included pregnant women who attended aquatic physiotherapy exercises in Kaunas city at P. Mažylis Maternity Hospital (department of physical medicine and rehabilitation) and at Šilainiai Outpatient Clinic as well as pregnant women undergoing gynecology check-ups but not attending physical therapy. The study included only nulliparous women.

Before the $1^{\text {st }}$ measurement, the test of diastasis recti was performed in order to eliminate the subjects with this disorder from the study. The study enrolled pregnant women with body mass index of 18.5-24.9 before pregnancy. The women who underwent cesarean section for delivery were excluded from analyses. The researchers obtained the permission from Kaunas Regional Biomedical Research Ethics Committee and written informed consent from study subjects.

Measurement 1 was conducted in 28-35 weeks of gestation and the intensity of low back pain (assessed by SAS) as well as core stability (assessed by "Stabilizer") in back and side positions were tested. Measurement 2 took place in 8-9 weeks after delivery and repeated the procedures mentioned above, but it also included tests for the activity of TrA in abdominal position and test of diastasis recti.

The study started with 47 pregnant women of working age, without any pathology of pregnancy or musculoskeletal system. Among them, 24 were attending aquatic physical therapy exercises (3 times per week for $45 \mathrm{~min}$ ) and 23 women were not. After delivery, three women from the former subgroup and four women from the latter were excluded from later analyses due to cesarean section, thus for Measurement 2 the total of 21 subjects in physical therapy gym group (2 times per week for $45 \mathrm{~min}$ ) and 19 subjects without 
physical therapy remained. These two groups were divided into two subgroups each - with and without maternity support garment. In total, this generated four subgroups of study including women:

- attending physical therapy exercises and wearing maternity support garment (during the whole period of research) $(n=9)$,

- attending physical therapy exercises but not wearing maternity support garment $(n=12)$,

- not attending physical therapy exercises but wearing maternity support garment (during the whole period of research) $(n=10)$,

- not attending physical therapy exercises and not wearing maternity support garment $(\mathrm{n}=9)$.

Mean age of study subjects was $27.2 \pm 3.9$ years, gestation stage by Measurement 1 was $31.2 \pm 2.7$ weeks.

\section{Measurements}

Intensity of low back pain (SAS). Study participants were asked to describe and show the most painful point in back area and express the intensity of pain from 0 to $10 \mathrm{pts}$. The participants pointed the intensity of pain on the scale independently.

Spinal stability. Spinal stability and objectively measured activity of TrA was evaluated using "Stabilizer". Testing. The women were asked to perform raising leg movements slowly, with TAM extension and spinal stabilization before that. The women were lying on a flat surface (on a couch). The evaluation of $\operatorname{Tr} A$ function and spinal stability during pregnancy (Measurement 1) was conducted in two positions:

- Back position: legs are knee bent, feet are on a surface. Device pillow is set below the waist. By expiration, the woman has to exert $\operatorname{Tr} A$ and try to keep the waist as stable as possible moving slowly with one leg. In 5 seconds she has to bend the hip (knee bent position) and in 5 seconds to make a movement back. In the same way she repeats the motions with the opposite leg.

- Side position: bearing leg is knee bent, the opposite leg is straight. Device pillow is set at waist side, between iliac crest and ribs. In spinal stabilization by TrA contraction, a woman has to move the hip to line of the shoulder slowly and evenly in 5 seconds and then move back in 5 seconds. The motion should be based rather on hip joint than on lateral waist movement. Before the movement, stabilizer pressure is set at $40 \mathrm{~mm} \mathrm{Hg}$ and during the movement the scale changes are observed. The measurement was performed twice and their arithmetic mean was used for the analyses.

The evaluations of $\operatorname{TrA}$ function and core stability after delivery (Measurement 2) were conducted in three positions. The first two positions were analogue to Measurement 1 , while the third position was as follows:

Abdominal position performed lying on abdomen and making contracting movement of abdominal wall. A woman is asked to lie on belly with neck and head relaxed and kept at middle line of the body. Device pillow is set at lower abdomen so that the distal margin of pillow would converge with anterior iliac line. The "Stabilizer" pressure is set at $70 \mathrm{~mm} \mathrm{Hg}$. A woman is asked to contract her lower abdomen slowly without supporting movements of spinal cord, hips, shoulders or pelvis, and keep such position for 10 seconds with regular breathing.

Decreasing pressure on "Stabilizer" manifests in negative numbers, which shows improving TrA activity. The study results were considered as positive if the pressure on device decreased to $-1 \mathrm{~mm} \mathrm{Hg}$ (in ideal case to $-10 \mathrm{~mm} \mathrm{Hg}$ ). However, if the pressure increased, this was observed in positive numbers on the device and showed improper contraction of TrA which in turn was considered as negative performance (Garnier et al., 2009). The measurement was performed twice and their arithmetic mean was used for analyses. Since assessment of spinal stability had both positive and negative values they were ranked to 5 ranges with certain values each (Table). Without ranking the sum of positive and negative values would have been zero and would distort the results of effect.

Table. Ranked values of spinal stability

\begin{tabular}{|l|c|l|}
\hline \multicolumn{1}{|c|}{$\mathbf{m m H g}$} & Rank & \multicolumn{1}{c|}{$\mathbf{~ m m H g}$} \\
\hline$[-2 ; 0] \mathrm{mmHg}$ & 0 & {$[0 ; 2] \mathrm{mmHg}$} \\
\hline$[-6 ;-3] \mathrm{mmHg}$ & 1 & {$[3 ; 6] \mathrm{mmHg}$} \\
\hline$[-13 ;-7] \mathrm{mmHg}$ & 2 & {$[7 ; 13] \mathrm{mmHg}$} \\
\hline$[-20 ;-14] \mathrm{mmHg}$ & 3 & {$[14 ; 20] \mathrm{mmHg}$} \\
\hline$[-28 ;-21] \mathrm{mmHg}$ & 4 & {$[21 ; 28] \mathrm{mmHg}$} \\
\hline
\end{tabular}

Diastasis recti. Testing: a woman had to lie down on her back with bent legs, then slowly raise her head and shoulder from the floor as if trying to reach the knees with hands - as long as lower edge of scapula was not touching the floor. The therapist 
had to touch the woman's abdomen horizontally and diagonally at midline of abdomen to umbilicus. Result was considered as positive if at least two fingers were able to fit in the gap (Janušoniene, Bacevičienè, 2006).

Statistical analysis. Data were analyzed using statistical package SPSS for Windows 16.0. Quantitative variables were described in means \pm standard error of the mean (SEM). Comparison of independent samples was performed using non-parametric Mann-Whitney-Wilcoxon test, comparison of related samples - using nonparametric Wilcoxon test. Quantitative variables were described in percent. Homogeneity of samples was assessed using chi-squared test, equality of distributions - using proportion equation test. Statistical significance was set at $\mathrm{p}<0.05$.

\section{RESEARCH RESULTS}

Low back pain and physical therapy attendance. The results of low back pain assessment revealed (Figure 1) that mean pain among pregnant women attending physical therapy but not wearing maternity support garment was about $8.4 \%$ (accordingly 4.58 and 5 points) lower than that of women not attending physiotherapy but wearing maternity support garment. After delivery at Measurement 2 this difference increased up to $42.4 \%$ (accordingly 2.42 and 4.2 points) $(\mathrm{p}<0.05)$.
Effect of physical therapy and maternity support garments on core stability in pregnancy and after delivery. Similarly, comparison of results during pregnancy showed that among women attending physiotherapy but not wearing maternity support garment, the spinal stability was better than that of women not attending physiotherapy but wearing maternity support garment (Figure 2): in back position, rank difference raising right leg was $0.7(17.5 \%)$, raising left leg $-0.78(19.5 \%)(\mathrm{p}<0.05)$. After delivery the difference increased to mean rank of 1.27 (31.8\%) and 1.18 (29.5\%), respectively. Here smaller value of rank shows better stability.

The comparison of groups was made based on side position results of spinal stability (Figure 2). During pregnancy, women attending physiotherapy but not wearing maternity support garment also showed better results than women not attending physiotherapy but wearing maternity support garment: mean rank difference at right leg contraction was $0.8(20 \%)$, at left leg $-0.68(17 \%)$ $(\mathrm{p}<0.05)$. After delivery the differences persisted and increased to $1.03(25.8 \%)$ and $0.85(21.2 \%)$, respectively $(\mathrm{p}<0.05)$.

Activity of rectus abdominis muscles in abdominal position. Assessment of activity of rectus abdominis muscles was conducted in this study only once - after delivery. Mean values of pressure changes across study subgroups are presented in Figure 3. We found that the mean
Figure 1. Low back pain differences depending on presence $(+)$ or absence (-) of physiotherapy and maternity support garment

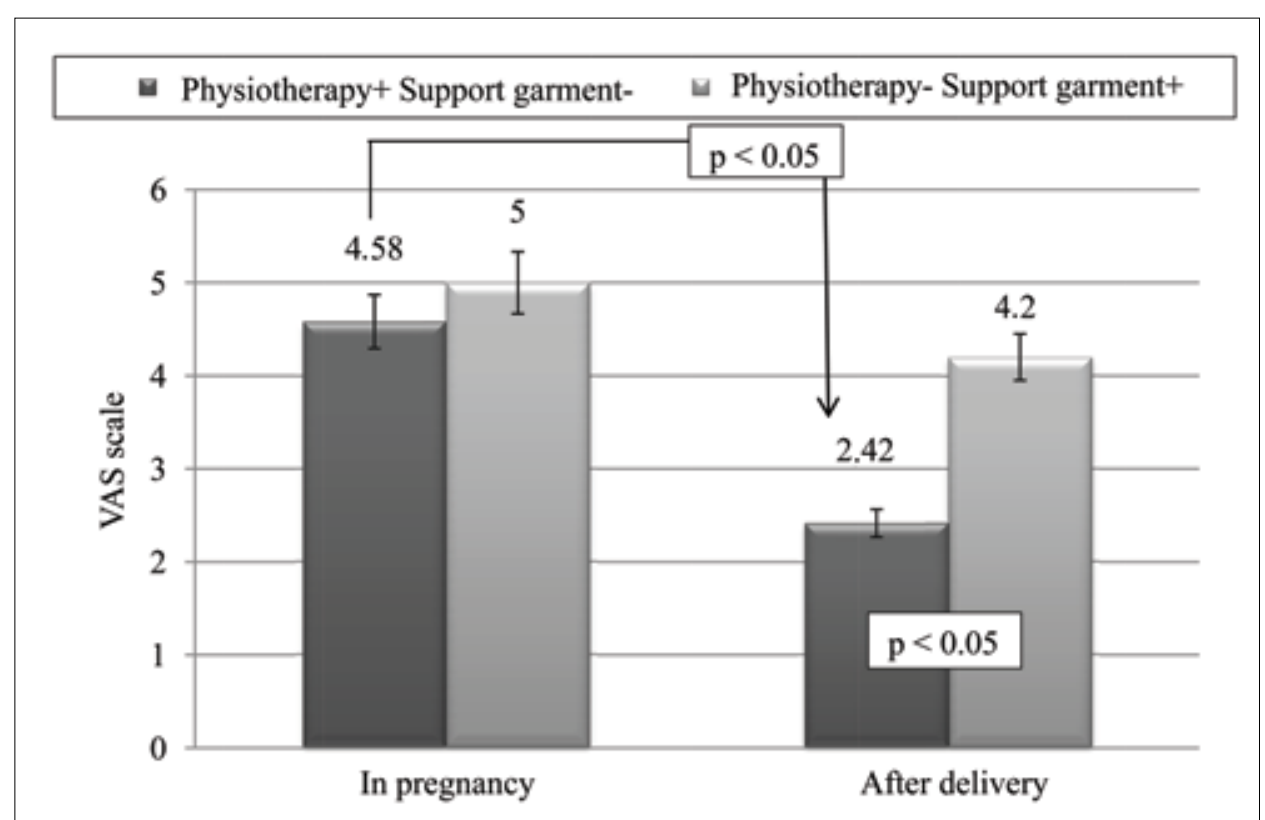


value among women attending physiotherapy and wearing maternity support garment was by 0.25 $\mathrm{mmHg}$ better than that among women attending physiotherapy but not wearing maternity support garment. With decreasing pressure, the activity of TAM increased. Among pregnant women who were not attending physiotherapy the pressure increased, which means that they were not able to activate their TAM. The pressure difference between women not attending physiotherapy and wearing maternity support garment was by $0.86 \mathrm{mmHg}$ better than that among women not attending physiotherapy and not wearing maternity support garment.

Distribution of diastasis recti and maternity support garment. The diastasis recti after delivery was observed only among women who did not attend physiotherapy exercises (Figure 4). Among women not attending physiotherapy but wearing maternity support garment $(n=10)$, diastasis recti
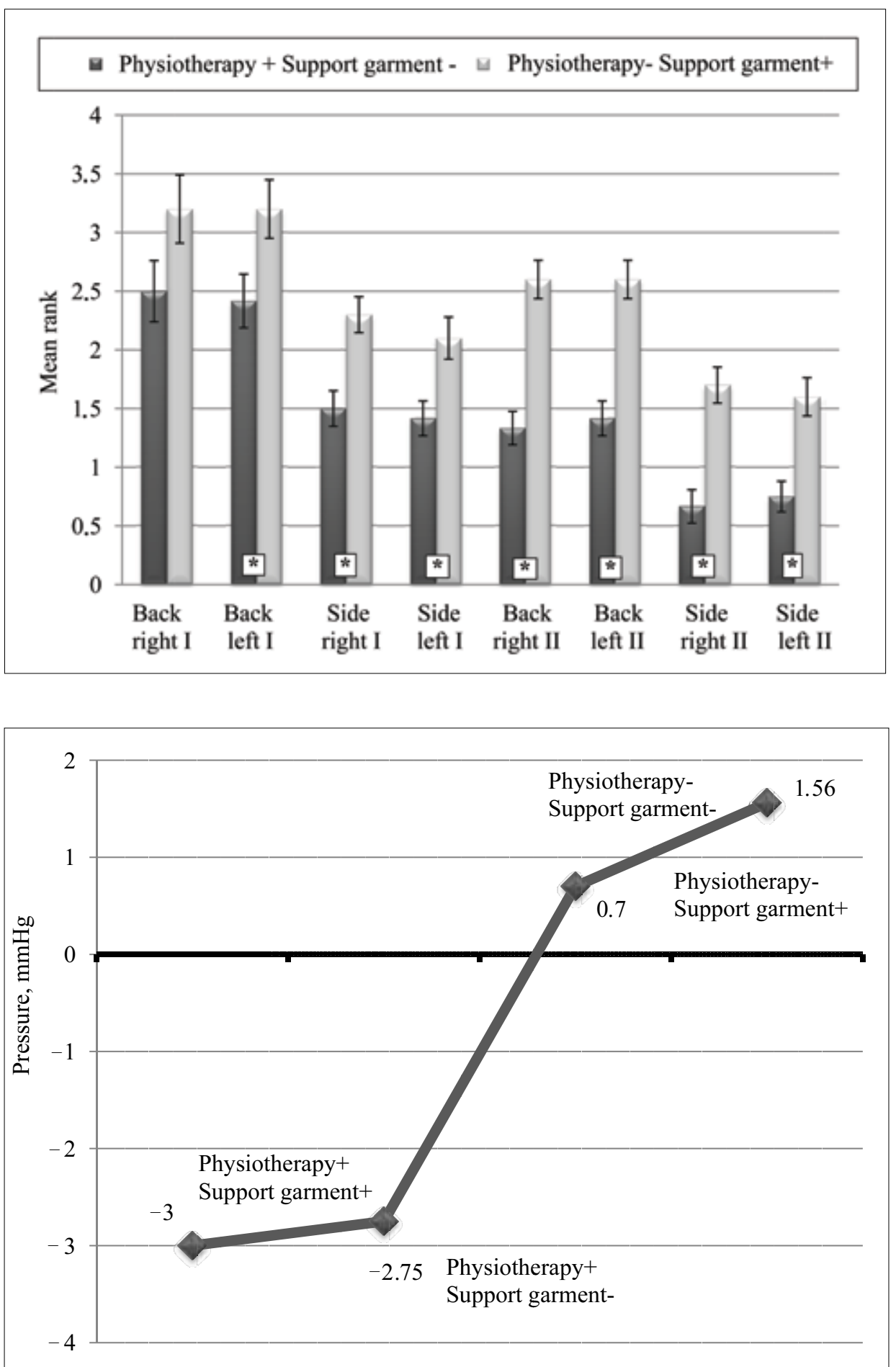

Figure 2. Spinal stability differences depending on presence $(+)$ or absence $(-)$ of physiotherapy and maternity support garment

Note. ${ }^{*}-\mathrm{p}<0.05$.

Figure 3. Activity of rectus abdominis muscles depending on presence $(+)$ or absence $(-)$ of physiotherapy and maternity support garment after delivery: abdominal position 
was observed in $30 \%$ of cases compared to $66.7 \%$ of women not attending physiotherapy and not wearing maternity support garment $(n=9)$, i. e. the difference was $36.7 \%$ of points.

\section{DISCUSSION}

Comparison of low back pain assessment results between women who were attending physiotherapy but not wearing maternity support garment and women who were not attending physiotherapy but wearing maternity support garment showed that physiotherapy was more effective than maternity support garment in reduction of low back pain during pregnancy (by $8.4 \%$ ) and after delivery (by $42.4 \% ; \mathrm{p}<0.05)$.

Low back pain intensity differences between women wearing and not wearing maternity support garment were similar both among women attending physiotherapy and not attending physiotherapy $(\mathrm{p}<0.05)$. Such results confirm the claims that wearing maternity support garment is effective for reduction of low back pains during pregnancy and after delivery. In general it can be stated that the most effective means of lowering low back pain during pregnancy and after delivery is physiotherapy and maternity support garment together.

Previously, in Lithuania there was one similar study conducted where low back pain intensity was assessed during pregnancy, before and after specific program of physical therapy. The authors found there that low back pain following the program reduced in intervention group ( $\mathrm{p}<0.05)$, but not in control group (Zachovajevienè et al., 2010). These results support the statements of scientists from a study in Korea (Shia et al., 2005). J. Gustafsson and L. Nillson-Wikmar (2008) applied specific program of physical exercises for the improvement of trunk muscles in women who suffered low back pain after delivery. Particular attention was paid to TrA and multifidi muscles. The results of that study showed that intensity of low back pain decreased for every woman under study and their activity increased.

Another study was conducted by A. Catherine who assessed the effect of maternity support garment on low back pain during the pregnancy. Her results demonstrated that maternity support garment was associated with statistically significant reduction of low back pain during rest time and daily activities
(Catherine, 2003). Researchers in Australia also conducted a similar study comparing two different models of maternity support garment in order to reduce pain in spinal and pelvic back area during pregnancy (Kalus et al., 2008). Wearing maternity support garment for three weeks was associated with statistically significant reduction of low back pain in both model groups - from 6.1 to 4.5 pts and from 6.0 to $4.7 \mathrm{pts}$, respectively.

In our study the results on spinal stability showed that among women attending physiotherapy but not wearing maternity support garment the stability was better than that among pregnant women not attending physiotherapy but wearing maternity support garment both before and after delivery $(\mathrm{p}<0.05)$. This supports the findings from other studies conducted in different countries. Positive effect of physical therapy was reported by A. Garshasbi and S. F. Zadeh (2005) and Lithuanian researchers who assessed the spinal stability also using stabilizer before and after specific physiotherapy program during pregnancy (Zachovajevienè et al., 2010).

TrA activity assessment after delivery showed that the best TrA activity was observed among women who were attending physiotherapy and wearing maternity support garment, while women not attending physiotherapy were not able to properly activate their TrA. Researchers from Ludwig Maximilian University of Munich also assessed TrA activity using stabilizer in abdominal position. Pressure change by at least $-1 \mathrm{~mm} \mathrm{Hg}$ was considered as positive. In contrast, increase of pressure showed improper TrA activity (Garnier et al., 2009).

In order to establish the association between diastasis recti and maternity support garment, we compared women not attending physiotherapy and we found that diastasis recti was by $36.7 \%$ points less common among women wearing maternity support garment compared to those not wearing it. However, this difference did not reach statistical significance. This could have happened due to very low sample sizes in subgroups $(n=10$ and $n=9$, respectively).Of note, the study analysis clearly showed that diastasis rectus was not observed in women attending physiotherapy. This supports positive effect of physiotherapy exercises in prevention of diastasis recti during pregnancy. Our results showed the trend that diastasis rectus is more prevalent in women without maternity support 
garment compared to those wearing maternity support garments. Therefore, it is expedient to wear maternity support garment during pregnancy since it activates TAM and prevents diastasis recti. Additionally, this restricts trunk movements that can also influence diastasis recti.

\section{CONCLUSIONS AND PERSPECTIVES}

1. Perceived low back pain after delivery was less expressed in women wearing maternity support garment both among women attending and not attending physical therapy exercises. Nevertheless, physical therapy is more effective in reducing low back pain than maternity support garment during pregnancy and after delivery.
2. Core stability after delivery improved among women attending physiotherapy exercises, but in case of maternity support garment it improved better. In contrast, in case of not attending physical therapy the core stability after delivery improved only for women wearing maternity support garment.

3. Core stability during pregnancy and after delivery was better among women attending physiotherapy but not wearing maternity support garment compared to women not attending physiotherapy but wearing maternity support garment.

4. Physical therapy and maternity support garment improves core stability and low back pain during pregnancy and has a positive effect on the activity of rectus abdominis muscles following delivery.

\section{REFERENCES}

Catherine, A. (2003). Use of a maternity support binder for relief of pregnancy-related back pain. Journal of Obstetric, Gynecologic, \& Neonatal Nursing, 32 (4), 495-502.

Garnier, K., Köveker, K., Rackwitz, B. (2009). Reliability of a test measuring transversus abdominis muscle recruitment with a pressure biofeedback unit. Physiotherapy, 95, 8-14.

Garshasbi, A., Zadeh, S. F. (2005). The effect of exercise on the intensity of low back pain in pregnant women. International Journal of Gynecology \&Obstetrics, 88 (3), 271-275.

Gustafsson, J., Nilsson-Wikmar, L. (2008). Influence of specific muscle training on pain, activity limitation and kinesiophobia in women with back pain post-partum A 'Single-subject research design'. Physiotherapy Research International, 13 (1), 18-30.

Janušonienè, L., Bacevičienè, R. (2006). Kineziterapijos pagrindai akušerijoje. Panevėžys: UAB Ciklonas.

Kalus, S., Kornman, L., Quinlivan, J. (2008). Managing back pain in pregnancy using a support garment: A randomised trial. BJOG An International Journal of Obstetrics and Gynaecology, 115, 68-75.

Lee, D. G., Lee, L. J., McLaughlin, L. (2008). Stability, continence and breathing: The role of fascia following pregnancy and delivery. Journal of Bodywork and Movement Therapies, 12, 333-348.

Mørkved, S., Åsmund, S. K., Schei, B., Lydersen, S., $\mathrm{B} \varnothing$, K. (2007). Does group training during pregnancy prevent lumbopelvic pain? A randomized clinical trial. Acta Obstetricia et Gynecologica Scandinavica, 86 (3), 276-282.

Shia, M., Lee, Y. S., Oh, H. E., Kim, J. S. (2005). Effects of a back-pain-reducing program during pregnancy for Korean women: A non-equivalent control-group pretest-posttest study. International Journal of Nursing Studies, 44 (1), 19-48.

Sneag, B. D., Bendo, J. A. (2007). Pregnancy-related low back pain. Orthopedics, 30 (10), 839-845.

Zachovajevienè, B. (2006). Atramos judamojo aparato pokyčiai ir stuburo skausmai néštumo metu. Kineziterapija, 1 (7), 15-19.

Zachovajevienè, B., Banionytė, J., Zachovajevas, P., Bulotienè, D. (2010). Skersinio pilvo raumens jëgos ir nugaros skausmo ryšys nėštumo metu taikant kineziterapiją. Ugdymas. Kūno kultūra. Sportas, 2 (77), 97-104.

Žuromskis, T. (2008). Nèštumas ir nugaros skausmas. Lietuvos akušerija ir ginekologija, T. 5, 3, 220-223. 


\title{
KINEZITERAPIJOS IR KORSETO POVEIKIS LIEMENS STABILUMUI IR APATINĖS NUGAROS DALIES SKAUSMUI NËŠTUMO METU IR PO GIMDYMO
}

\author{
Pavelas Zachovajevas ${ }^{1}$, Brigita Zachovajeviené ${ }^{2}$, \\ Jūratė Banionyte் $\dot{e}^{3}$, Arvydas Siaurodinas ${ }^{4}$ \\ Lietuvos kūno kultūros akademija ${ }^{1}$, Kaunas, Lietuva \\ Lietuvos sveikatos mokslu universitetas, Sporto institutas ${ }^{2}$, Kaunas, Lietuva \\ VŠL Kauno Šlainiu poliklinika ${ }^{3}$, Kaunas, Lietuva \\ Aleksandro Stulginskio universitetas ${ }^{4}$, Kaunas, Lietuva
}

\section{SANTRAUKA}

Tyrimo pagrindimas ir hipotezè. Nëštumo metu skersins pilvo raumuo būna labai pertemptas ir jo gebejjimas stabilizuoti juosmeninę stuburo dalį bei dubenį mažèja. Pakitęs stabilizavimo mechanizmas gali sukelti lètini nugaros skausmą. Todèl labai svarbu suteikti tinkamą pagalbą taikant veiksmingas nugaros skausmo mažinimo priemones. Hipotezé: kineziterapija yra veiksmingesnè nei liemens korseto dèvèjimas gydant apatinès nugaros dalies skausmus bei liemens stabilumą néštumo metu ir po gimdymo.

Tikslas - ivvertinti kineziterapijos ir korseto poveikị liemens stabilumui bei apatinès nugaros dalies skausmui nèštumo metu ir po gimdymo.

Metodai. 28-35 néštumo savaitę ir 8-9 savaitę po gimdymo buvo įvertintas visų tiriamujų nugaros skausmo intensyvumo suvokimas (SAS), liemens stabilumas bei skersinio pilvo raumens aktyvumas testuojami „Stabilaizeriu“ ir testu ivertinta tiesiujų pilvo raumenų diastazè.

Rezultatai. Kineziterapija yra 42,4\% veiksmingesné nei korseto dèvejimas kontroliuojant nugaros skausmą nèštumo metu ir po gimdymo $(\mathrm{p}<0,05)$. Geriausios skersinio pilvo raumens aktyvumo vertinimo reikšmès nustatytos lankančių kineziterapiją ir korsetą dévinčių moteru grupejje, o nelankančios kineziterapijos tiriamosios negalëjo taisyklingai aktyvuoti šio raumens. Tiesiojo pilvo raumens diastaze po gimdymo buvo nustatyta tik nelankančioms kineziterapijos nèščiosioms, o dèvinčių korsetą moteru grupẻje tai pasireiškẻ 36,7\% mažiau atvejų nei nenešiojančiu korseto grupès tiriamujų.

Aptarimas ir išvados. 1. Nugaros skausmo intensyvumo suvokimas po gimdymo buvo mažesnis korseta dèvinčių moterų tiek lankančių kineziterapiją, tiek nelankančių něščiuju grupėse $(p<0,05)$. Tačiau kineziterapija kontroliuojant nugaros skausmą yra veiksmingesnè, nei korseto dèvejimas néštumo metu ir po gimdymo $(p<0,05)$. 2. Lankančių kineziterapiją neeščiujų liemens stabilumo vertinimo rezultatai po gimdymo pagerejjo korsetą dèvinčių ir nedèvinčių néšiujju grupėse ( $p<0,05)$, tačiau tiriamujų dèvinčių korseta, rezultatai buvo geresni $(p<0,05)$. Nelankančių kineziterapijos néčiujų liemens stabilumo vertinimo rezultatai po gimdymo pageréjo tik korsetą nešiojusiuju grupeje $(\mathrm{p}<0,05)$. 3. Liemens stabilumas něštumo metu ir po gimdymo buvo didesnis lankančiu kineziterapiją be korseto něščiuju, nei nelankančiuju kineziterapijos su korsetu $(p<0,05)$. 4. Kineziterapija ir liemens korseto dèvejjimas turi įtakos liemens stabilumui néštumo metu ir teigiamai veikia skersinio pilvo raumens aktyvumą po gimdymo.

Raktažodžiai: akušerija, skersinio pilvo raumens aktyvumas, fiziniai pratimai.

Corresponding author Brigita Zachovajevienè

Lithuanian University of Health Sciences, Institute of Sport Jankaus str. 2, LT-50275 Kaunas

Lithuania

$\mathrm{Tel}+37069875901$

E-mail brigitaz@medi.lt 